\title{
Submandibular approach for orotracheal intubation in Oral and Maxillofacial
}

\section{Surgery and Traumatology}

\author{
Intubação orotraqueal com trajeto submandibular em Cirurgia e Traumatologia Buco-maxilo- \\ faciais \\ Intubación orotraqueal con vía submandibular en Cirugía y Traumatología Bucomaxilofacial
}

Received: 09/02/2021 | Reviewed: 09/09/2021 | Accept: 09/10/2021 | Published: 09/13/2021

\author{
Edela Puricelli \\ ORCID: https://orcid.org/0000-0003-1318-709X \\ Federal University of Rio Grande do Sul, Brazil \\ E-mail: epuricelli@uol.com.br \\ Deise Ponzoni \\ ORCID: https://orcid.org/0000-0003-2855-7495 \\ Federal University of Rio Grande do Sul, Brazil \\ E-mail: deise.ponzoni@ufrgs.br
}

\begin{abstract}
Introduction: Submandibular tracheal intubation is a technique that can be applied in Oral and Maxillofacial Surgery and Traumatology, as well as other surgical specialties. Its main advantages are helping in the surgical manipulation of the middle facial skeleton and jaw and allowing the intraoperative control of dental occlusion. The technique is an alternative to elective tracheostomy. Objective and case report: The article presents the treatment of an adult patient, with sequelae of multiple fractures in the face due to a car accident, with endotracheal intubation using submandibular approach. Final considerations: In large surgical manipulations of the face, the submandibular approach for tracheal intubation allows a faster, facilitated anatomical access with a lower risk of damage to adjacent structures when compared to other pathways. It also guarantees excellent cervical mobility, the possibility of wide manipulation and the use of occlusion as a guide for surgical intervention.
\end{abstract}

Keywords: Intubation; Oral surgery; Anesthesia general.

\section{Resumo}

Introdução: A intubação orotraqueal com trajeto submandibular é uma técnica que pode ser aplicada em Cirurgia e Traumatologia Buco-maxilo-faciais e outras especialidades cirúrgicas. Tem sua indicação diante da necessidade de manipulação cirúrgica do esqueleto fixo da face e mandíbula, permitindo o estabelecimento da oclusão transoperatória. A técnica é uma alternativa à realização da traqueostomia eletiva. Objetivo e relato do caso: $\mathrm{O}$ artigo tem por objetivo apresentar a intubação orotraqueal com trajeto submandibular, que foi aplicada em um paciente adulto, vítima de acidente automobilístico, com sequela de múltiplas fraturas em face. Considerações finais: Nas grandes manipulações cirúrgicas da face, o trajeto cirúrgico submandibular, para a passagem do tubo de anestesia, permite um acesso anatômico mais rápido, facilitado e com menor risco de danos às estruturas adjacentes, quando comparado com outras vias. Garante ainda, excelente mobilidade cervical, possibilidade de ampla manipulação e utilização da oclusão como guia para intervenção cirúrgica.

Palavras-chave: Intubação; Cirurgia bucal; Anestesia geral.

\section{Resumen}

Introdución: La intubación orotraqueal con vía submandibular es una técnica que se puede aplicar en Cirugía y Traumatología Buccomaxilofacial y otras especialidades quirúrgicas. Está indicado por la necesidad de manipulación quirúrgica del esqueleto fijo de rostro y mandíbula, permitiendo el establecimiento de oclusión intraoperatoria. La técnica es una alternativa a la realización de una traqueotomía electiva. Objetivo y relato de caso: El artículo tiene como objetivo presentar la intubación orotraqueal con vía submandibular, la cual se aplicó a un paciente adulto, víctima de un accidente automovilístico, con secuelas de múltiples fracturas en la cara. Consideraciones finales: En manipulaciones quirúrgicas mayores del rostro, la vía quirúrgica submandibular, para el paso del tubo de anestesia, permite un acceso anatómico más rápido, más fácil y con menor riesgo de daño a las estructuras adyacentes, en comparación con otras vías. También garantiza una excelente movilidad cervical, posibilidad de amplia manipulación y uso de la oclusión como guía para la intervención quirúrgica.

Palabras clave: Intubación; Cirugía bucal; Anestesia general. 


\section{Introduction}

Oral and Maxillofacial Surgery and Traumatology (OMFST) is the specialty of dentistry which includes the diagnosis and surgical and adjuvant treatment of diseases, traumas, lesions and congenital or acquired anomalies of the masticatory system and associated craniofacial structures. Given the characteristics of the specialty, the performance of the dentist includes the anatomical space of the upper area. Adequate management of the upper airway is important in OMFST as well as in other specialties such as Anaesthesiology and Otorhinolaryngology, which share the same space. The routine use of oral or nasal endotracheal intubation can be replaced by tracheostomy in selected cases (Banerjee, Jain, \& Behera, 2021; Grando \& Puricelli, 1997; Grando \& Puricelli, 2004; Grando \& Puricelli, 2018; Puricelli, 2005).

Elective tracheostomy before surgery may be a possibility in OMFST. However, this type of access to the upper airway is associated with a number of complications, especially in paediatric patients, and may be contraindicated in patients with cervical spine injury and tumours involving the surgical site (Anwer, Zeitoun, \& Shehata, 2007; Emara et al., 2019; Kaiser, Semanoff, Christensen, Sadoff, \& DiGiacomo, 2018).

As an alternative to the performance of elective tracheostomy, Hernández Altemir (1986) proposed the use of submental intubation to keep the surgical field clear, allowing the oral and maxillofacial surgeon and traumatologist to use intermaxillary immobilisation and to manipulate multiple fractures involving the fixed and mobile structures of the face in a single surgery aligning with dental occlusion. Another possibility is described as the submandibular approach for orotracheal intubation. Access to a more posterior portion of the tube, using an anatomically less complex approach, allows better access and safety (Anwer et al., 2007; Banerjee et al., 2021; Grando \& Puricelli, 1997; Grando \& Puricelli, 2004; Grando \& Puricelli, 2018; Katsnelson, Farcon \& Adamo, 1994; Puricelli, 2003; Puricelli, 2005; Stoll, Galli, Wächter, \& Bähr, 1994; Yun et al., 2020).

\section{Methodology}

This is a retrospective, descriptive and observational Clinical Case Report (Alsaywid \& Abdulhaq, 2019; Estrela, 2018) of a patient submitted to orotracheal intubation with a submandibular approach, under general anaesthesia in a hospital environment. Descriptive data were collected from physical and electronic medical records, after authorisation and signing by the patient of a Free and Informed Consent Form. This work was not submitted to a Research Ethics Committee. The case report derived from an unplanned healthcare attendance, with no previous project design. The literature was searched using the MeSH Database through the standardisation of keywords. The discussion was based on previous publications on the subject.

\section{Case Report}

A 44-year-old male patient with no history of previous diseases or allergies, the victim of an automobile accident, was referred by the basic health unit for evaluation of the sequelae of facial trauma suffered 90 days before. At the time of the accident, he received emergency care that included tracheostomy and suture of injuries of the facial soft tissues. After ten days in an intensive care unit and clinical hospitalisation, the patient was discharged without any treatment of the fractures. Extraoral clinical examination showed left facial asymmetry and a large skin scar in the frontal region involving the left eyebrow. The patient presented left enophthalmos, without any restriction of eye movements, and eyelid ptosis. The intraoral clinical examination showed dental malocclusion and limitation of oral opening.

Fan beam tomography revealed several fractures in the bones of the face, including a complex fracture of the left orbit, involving the zygomatic bone with a gap of about $0.7 \mathrm{~cm}$ from the frontozygomatic suture; a medial bulging of the 
medial orbital wall, partially obliterating the ipsilateral ethmoidal cells, in addition to lowering of the orbital floor, with no signs of herniation of the orbital content; fracture signs in the frontal process of the left maxilla without significant displacement; comminuted fracture without significant displacement of the fragments in the right fronto-zygomatic suture; fracture of the zygomatic arches, simple on the right and comminuted on the left, also involving the articular tubercle of the temporal bone, with misalignment of the fragments; anterior displacement of the left mandibular condyle; fracture of the medial and lateral plates of the left pterygoid process, with displacement of the fragments; fracture at the base of the left coronoid process, with a cranial displacement of about $2.0 \mathrm{~cm}$; comminuted fracture with slight sinking of the bones of the nose; and parasagittal fracture signs in the alveolar process of the maxilla on the right, between the lateral and central incisor teeth, extending through the hard palate to the posterior edge of the palatine bone, without displacement.

The treatment of trauma sequelae was conducted in two stages. The first stage consisted of the reconstruction of the fixed third of the face and the second one, performed six months later, used the mandibular osteotomies technique by Puricelli (2007) to restore functional occlusion. In the first stage, the patient was submitted to orotracheal intubation with a submandibular approach, as proposed by Puricelli (Grando \& Puricelli, 1997; Grando \& Puricelli, 2004; Grando \& Puricelli, 2018; Puricelli, 2003; Puricelli, 2005), with the objective of allowing wide access and better manipulation of fracture regions and also by providing surgical intermaxillary immobilisation (Figures 1 and 2). The patient was positioned in supine position, with the head slightly hyperextended. The anaesthesiologist performed orotracheal intubation with a wire-reinforced no. 6 silicone tube. After surgical antisepsis, a $2 \mathrm{~cm}$ skin incision was made in the left submandibular region, parallel to the lower edge of the mandible. Tissue divulsion was performed in a medial and superior direction, involving the platysma and mylohyoid muscles, using $14 \mathrm{~cm}$ Metzenbaum scissors. The anterior belly of the digastric muscle was avoided by contouring the base of the mandible in juxtaposition. The tissues were dissected in direction to the oral floor, resulting in access on the lingual face of the mandible, at the level of the lower premolars. An intraoral incision was performed in the space between the lingual face of the mandible and the secretory duct of the submandibular gland. Exposure of the scissors on the oral floor completed the surgical approach for the passage of the endotracheal tube. A vaginal speculum (no. 1) kept the tissues apart, to maintain the opening necessary for passage of the endotracheal tube. The patient was hyperventilated. The tube was disconnected, and its end was protected with a finger sleeve (latex or silicone), which was previously formatted and adapted. The end of the cuff inflation tube was grasped with Mixter forceps and pulled through the speculum. With the tube externalised through the submandibular incision, the anaesthesia device was reconnected, and ventilation was performed. The cuff was inflated, and the tube was fixed with sutures using 4-0 mononylon thread. This procedure allowed access to the middle third of the face and intraoperative control of the dental occlusion. The length of the tube in the intraoral space should be monitored for possible adaptations, avoiding selective intubation during the operative period. 
Figure 1: Stages of orotracheal intubation with submandibular approach.

A - Patient in supine position, with slightly hyperextended head. Orotracheal intubation with wire-reinforced tube.

B - Adaptation of the vaginal speculum in the left submandibular access area.

$\mathrm{C}$ - Tube passage. The endotracheal tube was disconnected and inserted through the opening for extraoral exposure.

D - Fixation of the tube by suture with mononylon thread.
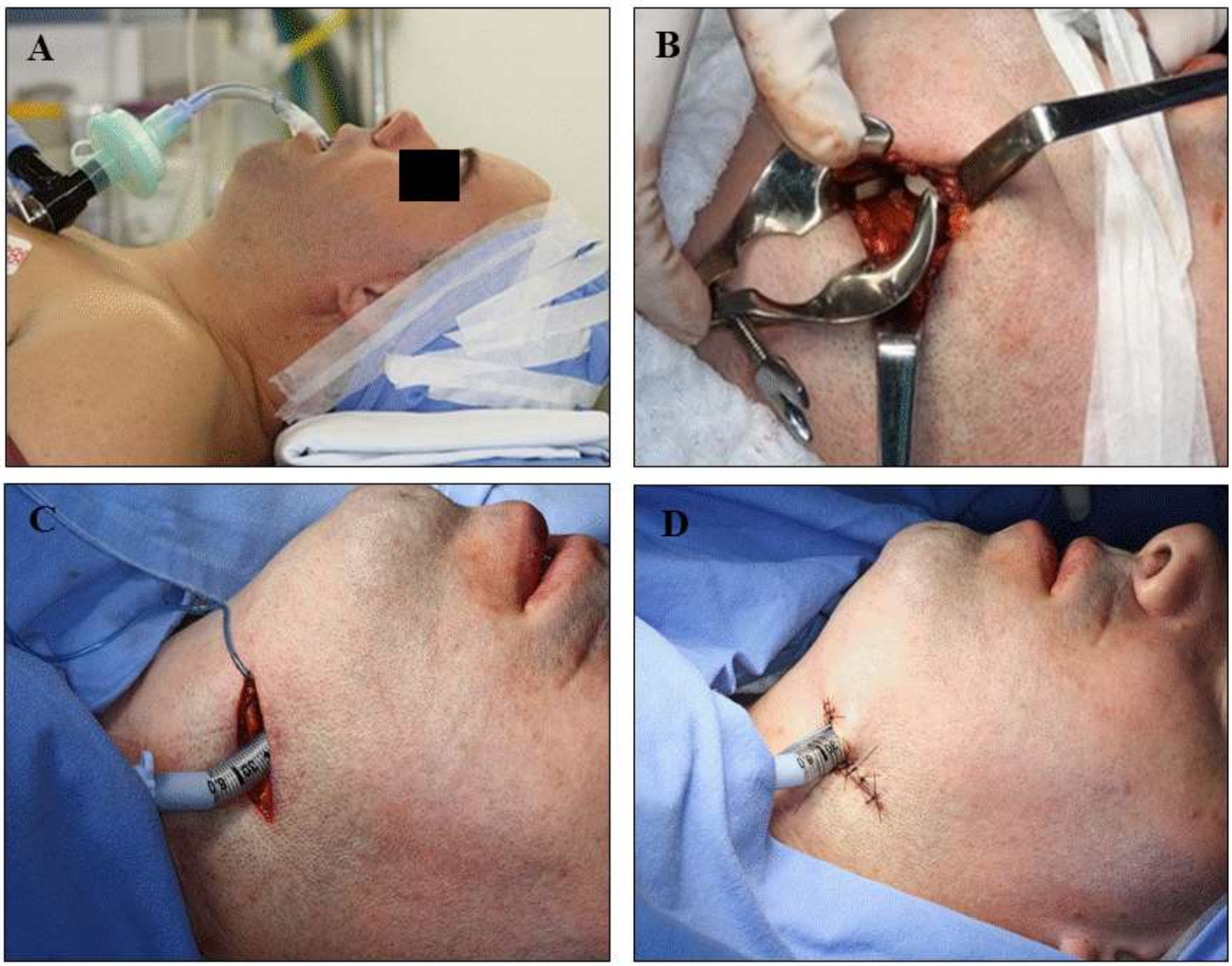

Source: Authors.

The orotracheal intubation with a submandibular approach is a fast and safe manoeuvre that allows free access to the face, with the possibility of establishing intraoperative dental occlusion. The tube is fixed with mononylon wire next to its outlet in the submandibular region. 
Figure 2: Intraoral aspect and apparatus used.

A - Intraoperative control of dental occlusion. The endotracheal tube may be manipulated between the right and left sublingual spaces.

B - Vaginal speculum and Mixter forceps.

C-Siliconised wire-reinforced no. 6 tube.

$\mathrm{D}$ - Connector removed from the tube.
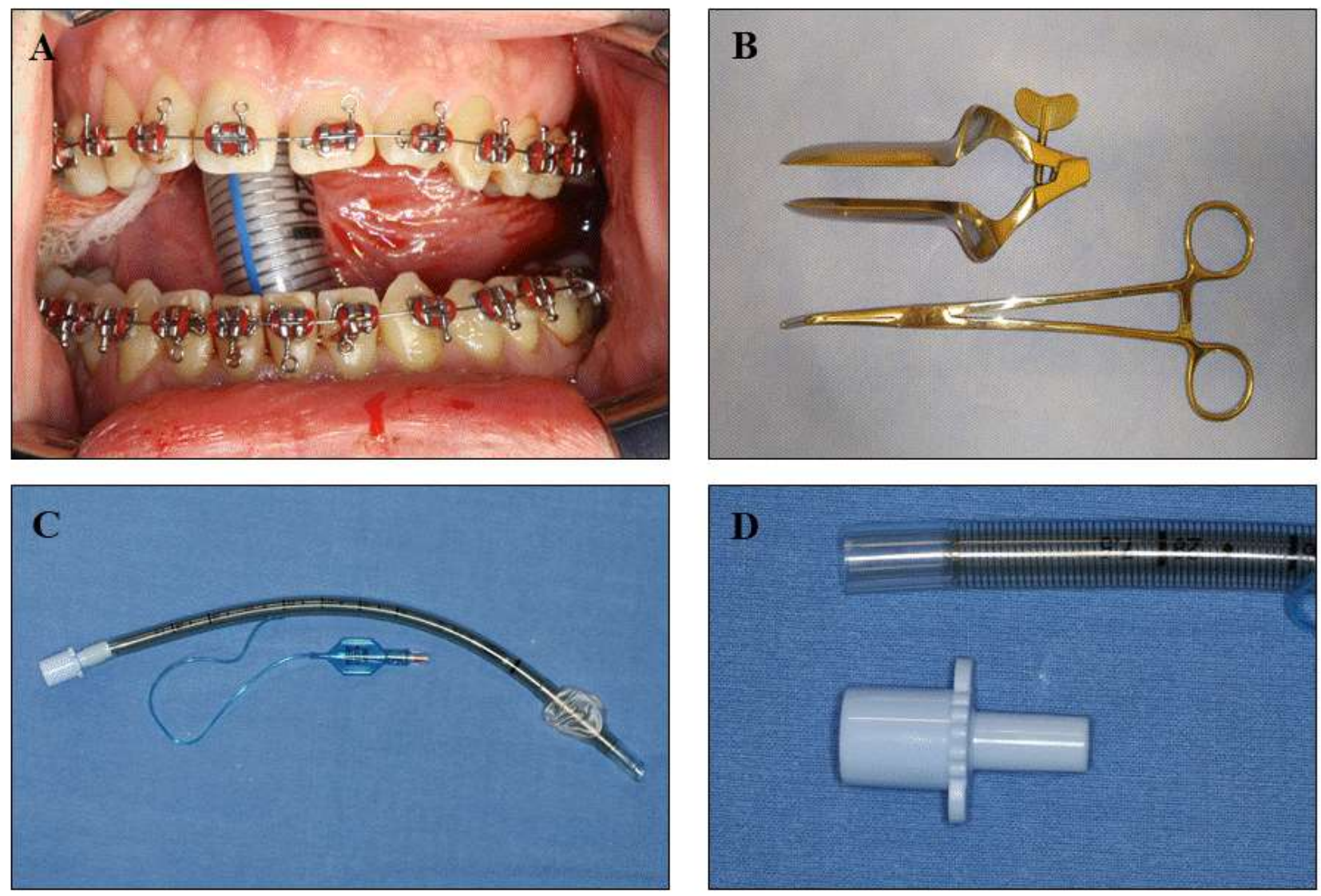

Source: Authors.

The devices used (Mixter forceps and speculum) are essential for performing externalisation of the tube through the tissues. Before performing orotracheal intubation with submandibular approach, the dentist or anaesthesiologist should test the removal of the tube connector.

\section{Discussion}

The treatment of panfacial trauma imposes challenges for maintaining the airway of patients. The standard solution of tracheostom before the operation is associated with several intraoperative complications such as airway loss, arterial desaturation, haemorrhage, pneumomediastinum, pneumothorax, and laryngeal nerve lesions. In addition, late complications may include respiratory tract infections, tracheal stenosis, tracheoesophageal fistula, and scarring (Kaiser et al., 2018). Orotracheal intubation techniques with a submental or submandibular approach represent a low-risk alternative to avoid 
elective tracheostomy (Anwer et al., 2007; Banerjee et al., 2021; Emara et al., 2019; Grando \& Puricelli, 1997; Grando \& Puricelli, 2004; Grando \& Puricelli, 2018; Hassanein, \& Abdel Mabood, 2017; Jung et al. 2020; Katsnelson et al., 1994; Lim, Parumo \& Shanmuhasuntharam, 2018; Martins, Castro, Ferraz, \& Simões, 2020; Mishra et al., 2020; Puricelli, 2003; Puricelli, 2005; Ramaraj et al., 2019; Stoll et al., 1994; Surman, Duffy, Anwar, Basyuni, \& Santhanam, 2021; Jun et al., 2020). It is also noteworthy that these alternatives require a shorter operative time than elective tracheostomy (Emara et al. 2019).

The submental route for endotracheal intubation proposed by Hernández Altemir (1986) has been employed and revisited by numerous authors. Even if its primary indication is associated with the surgical treatment of trauma (Anwer et al., 2007; Banerjee et al., 2021; Hassanein, \& Abdel Mabood, 2017; Kaiser et al., 2018; Martins et al., 2020; Mishra et al. 2020; Puricelli, 2005), the literature shows its use expanded for cases of orthognathic surgery, tumour resections and others (Goh, Loh, \& Loh, 2020; Mishra et al., 2020). The technique takes less operative time than tracheostomy (Emara et al., 2019; Faraj et al., 2013; Goh et al., 2020; Surman et al., 2021) and presents low complication rates (around 7\% of cases), the most common being superficial skin infection in the region of externalisation of the tube, hypertrophic scar and damage to the endotracheal tube itself (de Toledo, Bueno, Mesquita, \& Amaral, 2013; Goh et al., 2020). Different devices have been suggested, especially to facilitate the externalisation of the orotracheal tube, making the technique faster and easier and reducing the risk of complications. Among the proposals are the use of laparoscopic trocar (Jung et al., 2020), sterile camera cable drape (Yun et al., 2020) and a kit for transposition of the orotracheal tube composed of a conical punch device, coupled cylinder pliers and tongue retractor and drilling guide (Silveira, Costa \& Amaral, 2020).

The submandibular intubation technique offers a more posterior access, through an anatomically less complex path, resulting in a lower risk of damage to adjacent structures (Anwer et al., 2007; Banerjee et al., 2021; Grando \& Puricelli, 1997; Grando \& Puricelli, 2004; Grando \& Puricelli, 2018; Hassanein, \& Abdel Mabood, 2017; Katsnelson et al., 1994; Puricelli, 2003; Puricelli, 2005; Stoll et al., 1994; Yun et al., 2020).

The technique used in this case was initially described by Puricelli (Grando \& Puricelli, 1997), with a surgical path in the submandibular region, in the medial region of the first lower premolar to the region of the first molar. A disposable wirereinforced tube with low pressure and high-volume cuff is used. The separation and containment of the tissues with the use of a vaginal speculum allows the passage of the Mixter forceps, direct vision and grasping with fast and safe movement of the tube in the tissues. The use of the wire-reinforced endotracheal tube results in great malleability, without compromising its structure, avoiding mechanical obstruction. The submandibular position allows greater mechanical movement of the mandible (opening and closing the mouth) during surgery by keeping the tube exposed in the lateral region of the neck. It also prevents periostal detachment of the lingual face of the mandibular body and does not compromise the anterior belly of the digastric muscle. Periostal integrity avoids complications, including postoperative pain, and does not compromise glandular structures in the region, nor the lingual nerve. Before the tube is passed, it must be protected with a rubber casing so to prevent secretions from the oral cavity from entering (Grando \& Puricelli, 1997; Grando \& Puricelli, 2004; Grando \& Puricelli, 2018; Puricelli, 2003; Puricelli, 2005).

Contraindications for the submental or submandibular orotracheal intubation technique are related to situations such as the need for prolonged postoperative intubation, infection or malignant lesion in the area, and coagulopathy (Jacob, Tuncer, Kashan, \& Gurunluoglu, 2020). Extubation may be delayed until the patient is fully awake and the oedema controlled, to ensure airway protection. When the submental approach is used, the endotracheal tube should be maintained for less than $72 \mathrm{~h}$ due to the risk of laryngeal damage or pneumonia (Hernández Altermir, 1986). The submandibular approach allows a longer intubation period, under medical control, since the friction of the tube is smaller, thereby avoiding trauma to tissues in the pharyngeal area. 


\section{Final Considerations}

Submandibular tracheal intubation is an alternative technique to elective tracheostomy and can be indicated in several situations in Oral Maxillofacial Surgery and Traumatology. It allows the establishment of a definitive airway when transoperative occlusion is necessary to guide the intervention and surgical manipulation of the mandible and fixed facial structures at the same time.

The benefits associated with the minimum risk of complications and reduced operative time make the submandibular approach for orotracheal intubation an alternative that should be considered by specialty professionals.

Future clinical trials should be encouraged using the submandibular approach for orotracheal intubation, since its application is safe and promotes the most adequate positioning of the tube in the prone position.

\section{References}

Alsaywid, B. S., \& Abdulhaq, N. M. (2019). Guideline on writing a case report. Urology annals, 11(2), 126-131.

Anwer, H. M., Zeitoun, I. M., \& Shehata, E. A. (2007). Submandibular approach for tracheal intubation in patients with panfacial fractures. British journal of anaesthesia, 98(6), 835-840.

Banerjee, P. K., Jain, A., \& Behera, B. (2021). Submandibular intubation as an alternative for intra-operative airway management in maxillofacial fractures our institutional experience. Indian journal of anaesthesia, 60(8), 573-577.

Emara, T. A., El-Anwar, M. W., Omara, T. A., Anany, A., Elawa, I. A., \& Rabea, M. M. (2019). Submental intubation versus tracheostomy in maxillofacial fractures. Oral and maxillofacial surgery, 23(3), 337-341.

Estrela, C. (2018). Metodologia científica: Ciência, ensino e pesquisa. Arte Med.

Faraj, J. H., Al Khalil, M., Darwish, A., Faraj, I., El Zenati, H., Eltiraifi, Y., \& Nassir, F. (2013). Submandibular intubation. Qatar medical journal, 2012(2), 88-91.

Goh, E. Z., Loh, N., \& Loh, J. (2020). Submental intubation in oral and maxillofacial surgery: a systematic review 1986-2018. The British journal of oral \& maxillofacial surgery, 58(1), 43-50.

Grando, T. A. \& Puricelli, E. (1997). Anestesia em cirurgia buco-maxilo-facial e trauma buco-maxilar no manejo da via aérea. In Anestesiologia: princípios e técnicas (pp. 630-639). Porto Alegre: Artmed.

Grando, T. A. \& Puricelli, E. (2004). Anestesia em cirurgia bucomaxilofacial e trauma bucomaxilar no manejo da via aérea. In Anestesiologia: princípios e técnicas (pp. 941-953). Porto Alegre: Artmed.

Grando, T. A. \& Puricelli, E. (2018). Anestesia em cirurgia e traumatologia bucomaxilofaciais. In Anestesiologia (pp. 1104-1120). Porto Alegre: Artmed.

Hassanein, A. G., \& Abdel Mabood, A. M. (2017). Can Submandibular Tracheal Intubation Be an Alternative to Tracheotomy During Surgery for Major Maxillofacial Fractures? Journal of oral and maxillofacial surgery: official journal of the American Association of Oral and Maxillofacial Surgeons, 75(3), 508.e1-508.e7.

Hernández Altemir F. (1986). The submental route for endotracheal intubation. A new technique. Journal of maxillofacial surgery, 14(1), 64-65.

Jacob, D. D., Tuncer, F. B., Kashan, D. L., \& Gurunluoglu, R. (2020). Clinical Anatomy of Submental Intubation: A Review of the Indications, Technique, and a Modified Approach. Annals of plastic surgery, 84(2), 232-237.

Jung, I., Yoo, B. H., Ju, J. Y., Choi, S., Yon, J. H., Kim, K. M., Lim, Y. H., \& Lee, W. Y. (2020). Novel alternative for submental intubation - A case report. Anesthesia and pain medicine, 15(2), 247-250.

Kaiser, A., Semanoff, A., Christensen, L., Sadoff, R., \& DiGiacomo, J. C. (2018). Submental Intubation: an Underutilized Technique for Airway Management in Patients With Panfacial Trauma. The Journal of craniofacial surgery, 29(5), 1349-1351.

Katsnelson, T., Farcon, E., \& Adamo, A. R. (1994). More on submandibular endotracheal intubation for panfacial fractures. Journal of clinical anesthesia, 6(6), 527-528.

Lim, D., Ma, B. C., Parumo, R., \& Shanmuhasuntharam, P. (2018). Thirty years of submental intubation: a review. International journal of oral and maxillofacial surgery, 47(9), 1161-1165.

Martins, I. Q., Castro, M., Ferraz, P., \& Simões, I. (2020). Submental intubation is a viable alternative to tracheostomy in facial trauma. BMJ case reports, 13(5), e235537.

Mishra, R., Yadav, D., Tripathi, S., Kandel, L., Baral, P. P., Shubham, S., Karn, A., \& Dutta, K. (2020). Submental Intubations in Panfacial Fractures. Clinical, cosmetic and investigational dentistry, 12, 41-48.

Puricelli, E. (2005). Trauma bucomaxilofacial. In Rotinas de pronto socorro (pp. 396-409). Porto Alegre: Artmed. 
Research, Society and Development, v. 10, n. 12, e49101220158, 2021

(CC BY 4.0) | ISSN 2525-3409 | DOI: http://dx.doi.org/10.33448/rsd-v10i12.20158

Puricelli, E. (2003). Intubação oro-traqueal com um trajeto submandibular: uma alternativa na traqueostomia eletiva. RBC - Revista Brasileira de Cirurgia e Periodontia, 1(3), 238-241.

Puricelli E. (2007). A new technique for mandibular osteotomy. Head \& face medicine, 3, 15.

Ramaraj, P. N., Singh, R., Sharma, M., Patil, V., Arjun, K. R., \& Roy, B. (2019). Clinical evaluation of submental intubation as an alternative airway management technique in midface osteotomy. Journal of stomatology, oral and maxillofacial surgery, 120(5), 410-413.

Silveira, R. L., Costa, S. M., \& Amaral, M. (2020). New device for submental endotracheal intubation. The Journal of craniofacial surgery, 31 (2), $562-563$.

Stoll, P., Galli, C., Wächter, R., \& Bähr, W. (1994). Submandibular endotracheal intubation in panfacial fractures. Journal of clinical anesthesia, 6(1), 83-86.

Surman, K., Duffy, N., Anwar, Z., Basyuni, S., \& Santhanam, V. (2021). Submental intubation in craniomaxillofacial surgery. Anaesthesia, critical care \& pain medicine, 40(1), 100796.

Toledo, G. L., Bueno, S. C., Mesquita, R. A., \& Amaral, M. B. (2013). Complications from submental endotracheal intubation: a prospective study and literature review. Dental traumatology: official publication of International Association for Dental Traumatology, $29(3), 197-202$.

Yun, H. J., Rhee, S. H., Park, J. Y., Chae, Y. S., Han, J. H., Ryoo, S. H., Seo, K. S., Kim, H. J., \& Karm, M. H. (2020). A novel technique of submandibular intubation with a camera cable drape: a case report. Journal of dental anesthesia and pain medicine, 20(3), 155- 